\title{
POTENTIATION OF COPAÍBA OIL-RESIN WITH SYNTHETIC INSECTICIDES TO CONTROL OF FALL ARMYWORM ${ }^{1}$
}

\author{
WALDIANE ARAÚJO DE ALMEIDA², IGOR HONORATO LEDUÍNO DA SILVA², ANA CLÁUDIA VIEIRA DOS \\ SANTOS $^{2}$, AURÉLIO PAES BARROS JÚNIOR ${ }^{3}$, ADALBERTO HIPÓLITO DE SOUSA $^{4 *}$
}

\begin{abstract}
The control of Spodoptera frugiperda (J. E. SMITH) (Lepidoptera: Noctuidae) has been carried out mainly with pyrethroids and organophosphates insecticides. The continuous and indiscriminate use of synthetic insecticides, for decades, has led to the selection of resistant populations and has caused concerns for human health and the environment. An alternative is the use of botanical insecticides, including through the mixtures with synthetic insecticides. This study aimed to investigate the toxicity of copaiba oil-resin mixtures (COR) with deltamethrin, beta-cyfluthrin, beta-cypermethrin, methomyl, triazophos and chlorpyrifos for $S$. frugiperda. Bioassays were performed in the laboratory using newly hatched caterpillars on a contaminated surface (filter paper). Initially, concentration-mortality curves were established for each insecticide and COR. Based on the results, experiments were conducted to verify the effect of the COR mixtures with synthetic insecticides in the proportions of $1: 1\left(\mathrm{LC}_{25}+\mathrm{LC}_{25}\right)$ on larvae of $S$. frugiperda. Additionally, COR concentration-response curves were established by adding $1 / 8$ of the recommended rate of each insecticide. Notably, the use of this concentration for all insecticides was previously determined in bioassays, and no significant toxicity was found for $S$. frugiperda caterpillars. It was found that the toxicity of COR increased substantially by adding synthetic insecticides, especially with lower mixtures with beta-cypermethrin, methomyl and triazophos.
\end{abstract}

Keywords: Bioinsecticide. Additive effect. Synergism. Corn plague. Integrated pest management.

\section{POTENCIALIZAÇÃO DO ÓLEO-RESINA DE COPAÍBA COM INSETICIDAS SINTÉTICOS PARA O CONTROLE DA LAGARTA-DO-CARTUCHO}

\begin{abstract}
RESUMO - O controle de Spodoptera frugiperda (J. E. SMITH) (Lepidoptera: Noctuidae) tem sido realizado principalmente com inseticidas piretróides e organofosforados. O uso contínuo e indiscriminados de inseticidas sintéticos, durante décadas, tem ocasionado a seleção de populações resistentes, bem como preocupações em relação à saúde humana e ao meio ambiente. Uma alternativa é o emprego de inseticidas botânicos, inclusive por meio de misturas com inseticidas sintéticos. Assim, este trabalho teve por objetivo investigar a toxicidade de misturas do óleo-resina de copaíba (ORC) com os inseticidas deltametrina, beta-ciflutrina, beta-cipermetrina, metomil, triazofós e clorpirifós para $S$. frugiperda. Foram realizados bioensaios em laboratório utilizando-se lagartas recém-eclodidas em superfície contaminada (papel filtro). Inicialmente, foram estabelecidas curvas de concentração-mortalidade para cada inseticida e para o COR. A partir dos resultados obtidos foram realizados bioensaios para verificar o efeito das misturas do ORC com os inseticidas sintéticos nas proporções de 1:1 ( $\left(\mathrm{CL}_{25}+\mathrm{CL}_{25}\right)$ sobre lagartas de $S$. frugiperda. Adicionalmente, foram estabelecidas curvas de concentração-resposta do ORC adicionando-se $1 / 8$ da dose comercial de cada inseticida. Vale destacar que o uso desta fração para todos os inseticidas foi determinada em bioensaios preliminaries, não tendo apresentado toxicidade considerável para as lagartas de $S$. frugiperda. Constatou-se que a toxicidade do ORC aumentou substancialmente adicionando-se os inseticidas sintéticos, com menor destaque para as misturas com beta-cipermetrina, metomil e triazofós.
\end{abstract}

Palavras-chave: Bioinseticida. Efeito aditivo. Sinergismo. Praga de milho. Manejo integrado de pragas.

\footnotetext{
${ }^{*}$ Corresponding author

${ }^{1}$ Received for publication in 06/01/2016; accepted in 12/06/2016.

Paper extracted from master's dissertation of the first author.

${ }^{2}$ Posgraduate Program in Plant Production (Agronomy), Universidade Federal do Acre, Rio Branco, AC, Brazil; waldianearaujo@hotmail.com, ighonorato@yahoo.com.br, anavieira-85@hotmail.com.

${ }^{3}$ Departament of Plant Sciences, Universidade Federal Rural do Semi-Árido, Mossoró, RN, Brazil; aurelio.barros@ufersa.edu.br.

${ }^{4}$ Center for Biological and Natural Sciences, Universidade Federal do Acre, Rio Branco, AC, Brazil; adalberto@ufac.br.
} 


\section{INTRODUCTION}

The control of Spodoptera frugiperda (J. E. SMITH) (Lepidoptera: Noctuidae) has been carried out mainly with pyrethroids and organophosphates synthetic insecticides. The continuous and indiscriminate use of these products has favored the emergence of resistant populations (OMOTO; RODRIGUEZ, 2001; RÍOS-DÍEZ; SALDAMANDO -BENJUMEA, 2011; SALEEM et al., 2016). Among the main alternatives, it is worth mentioning the use of botanical insecticides (FAZOLIN et al., 2016; SANTOS et al., 2016) and transgenic crops, although there are historical reports on S. frugiperda-resistant populations for the latter (SANTOS-AMAYA et al., 2015; HORIKOSHI et al., 2016).

Usually, botanical insecticides are used as powders, extracts or oils, which are easy to obtain, and generally harmless to the applicator and consumers (ISMAN, 2000; CORREAA; SALGADO, 2011). More than 100,000 secondary metabolites with insecticidal properties have been identified from approximately 200,000 species of plants in the world, and they particularly belong to alkaloid, terpenoid, flavonoid, and quinone groups (POTENZA et al., 2004). These compounds have multiple modes of action on insects, particularly: acute toxicity, repellency, feeding inhibition, growth, development and reproduction (COITINHO et al., 2006; GERIS et al., 2008).

In this sense, the Amazon rainforest is the largest natural reservoir of the plant diversity of the planet, where each of its different forest environments has a rich and varied floristic contingent, often unique to a particular environment (OLIVEIRA; AMARAL, 2004). Despite the immense Amazonian plant diversity, the insecticide potential of species found in the forest itself is little known, since the related studies have become more frequent in the last decade (PEREIRA et al., 2008; SARRIA et al., 2011; GOUVÊA et al., 2010; LIMA-MENDONÇA et al., 2013).

Among numerous species found in the Amazon rainforest it is possible to highlight copaiba (Leguminosae-Caesalpinoideae) belongs to the family Caesalpinaceae and to the gender Copaifera sp. It is a native tree of Latin America and West Africa, with high rates in Brazil and widely distributed in the Amazon rainforest (FRANCISCO, 2005; ARAÚJO JÚNIOR et al., 2005). The copaiba oil comes from the flow through channels located in the plant log and it is collected through the tree trunk drilling, the volatile fraction (the distilled copaiba oil or essential oil) is obtained from oil-resin by steam distillation. This is basically composed of sesquiterpene oxygenated hydrocarbons, predominantly $\quad \beta$-caryophyllene, $\beta$-bisabolene, $\beta$-bergamoteno and $\beta$-selinene (VEIGA JUNIOR; PINTO, 2002). Recently, Cárdenas-Ortega et al. (2015) found that the essential oil from Salvia ballotiflora Benth (Lamiaceae), which also contains $\beta$-caryophyllene $(12.74 \%)$ among its major components, showed insecticidal activity in $S$. frugiperda, leading to a decrease in the viability of caterpillars and pupae. However, copaiba oil-resin (COR) has been shown to be toxic to Sitophilus zeamais Motschulsky (Coleoptera: Curculionidae) (SANTOS et al., 2015).

From a toxicological point of view the recognition of the potential insecticide of occurring plants in the Amazon flora, as copaíba, is relevant because of the range of secondary metabolites often found in vegetable insecticides (SANTIAGO et al., 2005; AMBROZIN et al., 2006; GERIS et al., 2008; SARRIA et al., 2011). These compounds are needed for the immediate survival of plant cells, but they serve as an evolutionary advantage to their own survival and reproduction, may also act as a natural defense pesticides against herbivores and pathogens (GOUVÊA et al., 2010; RANI; VENKATESHWARAMMA; DEVANAND, 2011). In the case of botanical insecticides, there are different modes of action, especially the toxic potential, repellency, feeding inhibition, development and reproduction of insects (ISMAN, 2000; ALVES et al., 2012; SANTOS et al., 2016).

Most research with insecticide plants are limited to traditional toxicity tests with little research, whose purpose is the enhancement of botanical insecticides through the mixtures. However, a way of using these botanical insecticides is through the mixtures of chemical insecticides. The objective of this study was to investigate the toxicity of copaiba oil-resin (COR) mixtures with synthetic insecticides as a management alternative against $S$. frugiperda.

\section{MATERIAL AND METHODS}

\section{Colony-stock}

The colony-stock of $S$. frugiperda was established by some copies from the Agroforestry Research Center of Acre (EMBRAPA/AC). The creation of the insects was adapted from procedures adopted by Bavaresco et al. (2002). The newly hatched caterpillars were placed in separate plastic containers that had holes in the lid $(5.0 \times 5.5 \mathrm{~cm})$ and contained artificial food, as described by Kasten Júnior, Precetti and Parra (1978), where they were kept until they reached the pupal stage. Later, the adults were sexed and after adult emergence, they were transferred to the PVC cages to obtain new oviposition and newly hatched caterpillars.

\section{Insecticides and copaiba oil}

The following insecticides were used: deltamethrin (Pyrethroid) (Decis ${ }^{\circledR} \quad 25$ EC), 
Beta-cypermethrin (Pyrethroid) (Akito), Beta-cyfluthrin (Pyrethroid) (Turbo), triazophos (organofosforado) (Hostathion $400 \quad \mathrm{BR}$ ), Chlorpyrifos (Organophosphorus) (Klorpan 480 EC) and Methomyl (Carbamate) (Lanate BR). All these insecticides were purchased in the agricultural stores. The COR was from samples of Cazumbá-Iracema and Flona Macauã/Sena Madureira reserves, provided by Agroextrativista Cooperative of Rural Producers of Vale do Rio Iaco - Sena Madureira / AC. COR extraction was performed through perforations in the trunk of the copaiba tree with an auger, about 1 to $1.5 \mathrm{~m}$ above the base of the plant. Then, 3-4-inch PVC pipes were inserted into the holes through which the oil drained.

Concentration-mortality curves for insecticides and COR

It has been determined, initially, the toxicity of each pesticide and COR to newly hatched caterpillars of $S$. frugiperda using concentration-mortality curves. Initially, preliminary tests to estimate the highest concentrations did not occur death of larvae were performed (lower end) and the lowest concentration that occured with increased mortality (upper end). Based on the data obtained, were established, for each insecticide and COR, five to six concentration ranges for the definitive bioassay. The final concentrations ranged from 2.08 to $8.33,1.25$ to $20.00,10.00$ to 80.00 , 53.75 to $430.00,80.00$ to 640.00 , and 42.86 to $640.00 \mathrm{mg} \mathrm{L}^{-1}$ for deltamethrin, beta-cyfluthrin, beta-cypermethrin, methomyl, triazophos, and chlorpyriphos, respectively. For copaiba oil, the final concentrations ranged from $1.56 \%$ to $25 \%(\mathrm{v} / \mathrm{v})$. Acetone was used as a solvent in both bioassays.

Exposure of insects was accomplished by contact with contaminated surface, where newly hatched caterpillars were placed in separate Petri dishes $(5.0 \mathrm{~cm}$ diameter $\times 1.2 \mathrm{~cm}$ height $)$ containing filter papers $(5.0 \mathrm{~cm}$ diameter $)$ impregnated with test solutions $(200 \mu \mathrm{L})$. Petri dishes were then covered with voile fabric to allow gas exchange. The assessment of mortality was performed at 24 hours after the start of exposure of larvae to insecticides and to COR. Larvae that showed no movement when touched lightly with a brush were considered dead. We used 5 replications, each replicate consisting of 10 larvae. The concentration-response data were subjected to probit analysis (SAS INSTITUTE, 2011).

\section{Bioassays with mixtures of COR and insecticides}

Initially, experiments were conducted to verify the effect of COR mixtures with synthetic insecticides in the proportions of 1:1 $\left(\mathrm{LC}_{25}+\mathrm{LC}_{25}\right)$ on larvae of $S$. frugiperda. The exposure of larvae was made by using the same procedure used in bioassays of toxicity. Four replications were used, each replicate consists of 10 larvae. Mortality was assessed after 24 hours. The efficiency of the treatments was determined according to Abbott's formula. The data were analyzed by analysis of variance (ANOVA) and Tukey test $(P \leq 0.05)$. Shapiro-Wilk and Cochran tests were used to check normality of residuals and homogeneity of variances, respectively.

Concentration-response curves were established when COR was combined with any one of the following insecticides: triazophos (organophosphorus), methomyl (carbamate), or beta-cypermethrin (pyrethroid). These three insecticides were chosen because of their high efficiency in bioassays when combined with COR at a ratio of $1: 1\left(\mathrm{LC}_{25}+\mathrm{LC}_{25}\right)$, with each chemical group of insecticide. COR concentrations, previously established in bioassays as ranging from $1.56 \%$ to $25 \%$, were combined in a solution containing $1 / 8$ th of the recommended concentration of each commercial insecticide $(5.00,53.75$, and $80.00 \mathrm{mg} \mathrm{L}^{-1}$ of beta-cypermethrin, methomyl, and triazophos, respectively). Notably, this $1 / 8$ th fraction for each insecticide was also determined through previous bioassays, and no significant toxicity was observed for newly hatched caterpillars of $S$. frugiperda. Acetone was used as a solvent in both bioassays.

Each mixture was tested on $5.0 \mathrm{~cm}$ diameter filter paper impregnated with five concentrations, where it was applied $200 \mu \mathrm{L}$ pipetter of each concentration, inside Petri dishes $(5.0 \mathrm{~cm}$ diameter $\times 1.2 \mathrm{~cm}$ height $)$. Petri dishes containing caterpillars were covered with voile fabric to promote gas exchange. Four replications were used, each replicate being composed of ten (10) larvae. The assessment of mortality was made by counting the number of live and dead insects, 24 hours after the start of the bioassays, considering dead insects those that had not move when touched gently with a brush. The concentration-response data were subjected to probit analysis (SAS INSTITUTE, 2011).

\section{RESULTS AND DISCUSSION}

The results of the concentration-mortality curves of insecticides to the larvae are shown in Table 1. The deltamethrin showed greater toxicity to larvae and the chlorpyrifos was the least toxic. These 
curves were established for testing the efficacy of commercial products and finding tests with concentrations of mixes. The probit model was suitable for concentration-mortality data obtained with insecticides, based on the low values $\chi 2$ and the high values $P$, obtained for each

Table 1. Relative toxicity of synthetic insecticides to $S$. frugiperda.

\begin{tabular}{|c|c|c|c|c|c|}
\hline Insecticide & $\begin{array}{l}\text { Inclination } \pm \\
\text { S.E. }{ }^{1}\end{array}$ & $\begin{array}{c}\mathrm{LC}_{25} \\
(\mathrm{FI} 95 \%) \mathrm{mg} \mathrm{L}^{-1}\end{array}$ & $\begin{array}{c}\mathrm{LC}_{50} \\
(\mathrm{FI} 95 \%) \mathrm{mg} \mathrm{L}^{-1}\end{array}$ & $\chi^{2}$ & $P$ \\
\hline Deltamethrin & $5.22 \pm 0.75$ & $\begin{array}{c}2.75 \\
(2.25-3.19)\end{array}$ & $\begin{array}{c}3.71 \\
(3.21-4.28)\end{array}$ & 1.04 & 0.31 \\
\hline Beta-Cyfluthrin & $3.16 \pm 0.44$ & $\begin{array}{c}4.15 \\
(3.32-4.97)\end{array}$ & $\begin{array}{c}6.79 \\
(5.68-8.41)\end{array}$ & 3.20 & 0.36 \\
\hline Beta-Cypermethrin & $1.70 \pm 0.49$ & $\begin{array}{c}12.83 \\
(5.69-17.88)\end{array}$ & $\begin{array}{c}31.85 \\
(23.07-65.52)\end{array}$ & 1.13 & 0.28 \\
\hline Methomyl & $3.68 \pm 0.43$ & $\begin{array}{c}58.81 \\
(47.30-69.45)\end{array}$ & $\begin{array}{c}89.73 \\
(76.58-104.75)\end{array}$ & 3.06 & 0.38 \\
\hline Triazophos & $4.91 \pm 0.82$ & $\begin{array}{c}104.31 \\
(83.40-123.31)\end{array}$ & $\begin{array}{c}143.07 \\
(120.91-172.67)\end{array}$ & 4.04 & 0.13 \\
\hline Chlorpyrifos & $2.19 \pm 0.48$ & $\begin{array}{c}227.60 \\
(172.02-326.97)\end{array}$ & $\begin{array}{c}462.63 \\
(323.10-992.15)\end{array}$ & 1.47 & 0.48 \\
\hline
\end{tabular}

${ }^{1}$ S.E. $=$ Standard error; LC $=$ Lethal concentration; FI $95 \%=$ Fiducial interval at $95 \%$ probability; $\chi^{2}=$ Chi-square; $P=$ Probability.

A significant variation among COR and insecticides mixtures at a ratio of $1: 1$ were observed $\left(\mathrm{LC}_{25}+\mathrm{LC}_{25}\right)\left(\mathrm{F}_{5 ; 18}=283.61 ; P<0.01\right)$. In addition, the residues did not exhibit normal distribution $\left(\mathrm{W}_{\mathrm{c}}=0.88\right.$ and $\left.P<0.01\right)$, but homogeneity of variances was detected $\left(\mathrm{C}_{\mathrm{c}}=0.58\right.$ and $\left.P>0.05\right)$. It is observed in Figure 1 that the mixture of copaiba-oil and insecticides in proportions of $1: 1\left(\mathrm{LC}_{25}+\mathrm{LC}_{25}\right)$ concentration-mortality curve $(\chi 2<4.1 ; \quad P>0.05)$ With regard to $\mathrm{COR}$, the following $\mathrm{LC}_{25}$ and $\mathrm{LC}_{50}$ (\%) v/v were determined: $3.85(3.20-4.45)$ and 5.36 (4.65-6.29), respectively $(\chi 2=3.951 ; P>0.05)$.

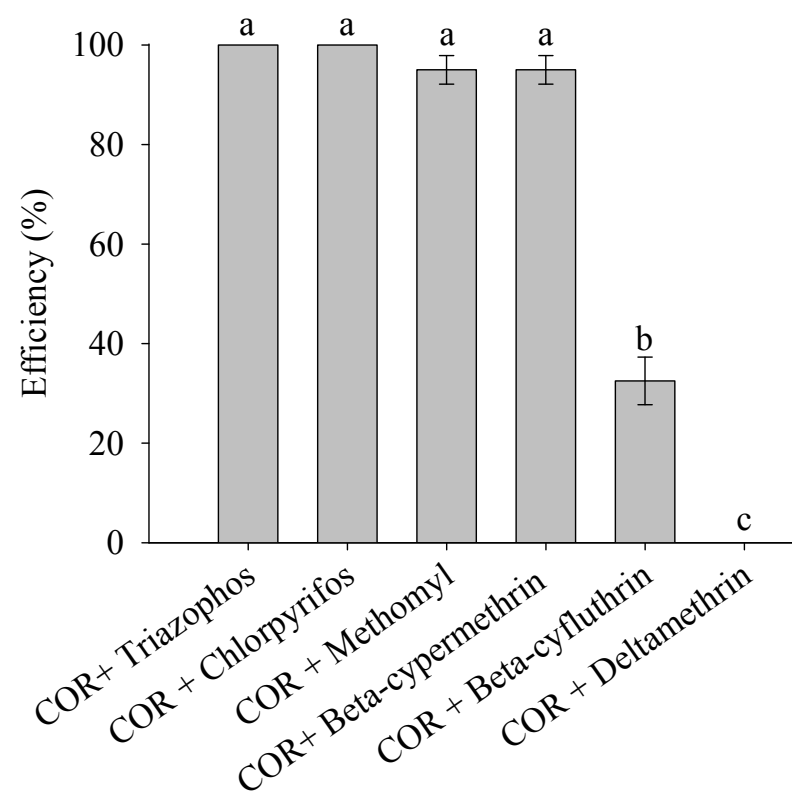

Figure 1. Efficiency $(\%)( \pm \mathrm{SE})$ of copaiba oil mixtures with synthetic insecticides in proportions of $1: 1\left(\mathrm{LC}_{25}+\mathrm{LC}_{25}\right)$ on larvae of $S$. frugiperda. Means followed by the same letter do not differ statistically with each other by Tukey Test $(P<0.05)$. 
The results of the concentration-response curves of COR in admixture with insecticides (1/8 of the recommended rate of each insecticide) are shown in Table 2. In these bioassays were used only the following insecticides: triazophos (organophosphorus), methomyl (carbamate) and beta-cypermetrin (pyrethroid). They were chosen because they exhibited high efficiency when combined with COR at a ratio of $1: 1$, and at least one insecticide of each chemical group was represented. Chlorpyriphos was not used in the synergism tests because it exhibited a high $\mathrm{LC}_{50}$ value in the toxicity bioassays (Table 1). The probit model was also suitable for the concentration-mortality data obtained with the mixtures (insecticides + COR), based on the low value of $\chi^{2}$ and high values $P$, obtained for each concentration-mortality curve $\left(\chi^{2}<7.2 ; \quad \mathrm{P}>0.05\right)$ (Table 2). The $\mathrm{LC}_{50}$ of the copaiba oil separately was $5.36 \% \mathrm{v} / \mathrm{v}$. Moreover, there was a substantial reduction when mixed with triazophos $(1.92 \%)$, methomyl (1.82\%) and beta-cypermetrin (1.71\%), where synergism ratio ranged from 2.79 to 3.13 times. In general, lower amounts of COR were required to kill insects when insecticides were added to mixtures (Table 2). The results indicate that the copaiba oil toxicity was substantially increased in all mixtures when no harmful concentrations of triazophos, methomyl, and beta-cypermethrin were used.

Table 2. Toxicity of COR mixtures with insecticides (1/8 of the recommended rate of each pesticide) to S. frugiperda.

\begin{tabular}{lccccc}
\hline Mixture & $\begin{array}{c}\text { Inclination } \pm \\
\text { S.E. }\end{array}$ & $\mathrm{LC}_{50}(\mathrm{FI} 95 \%)(\%) \mathrm{v} / \mathrm{v}$ & $\begin{array}{c}\mathrm{RT} \\
\left(\mathrm{LC}_{50}\right)\end{array}$ & $\chi^{2}$ & $P$ \\
\hline COR & $4.71 \pm 0.69$ & $5.36(4.65-6.29)$ & - & 3.94 & 0.13 \\
COR + Triazophos & $3.65 \pm 0.49$ & $1.92(1.61-2.29)$ & 2.79 & 3.99 & 0.13 \\
COR + Methomyl & $3.68 \pm 0.49$ & $1.83(1.51-2.21)$ & 2.92 & 2.03 & 0.36 \\
COR + Beta-cypermetrin & $2.65 \pm 0.31$ & $1.71(0.96-1.43)$ & 3.13 & 7.19 & 0.12 \\
\hline
\end{tabular}

${ }^{1}$ S.E. $=$ Standard error of the mean; LC $=$ Lethal concentration; FI 95\% = Fiducial interval at 95\% probability; $\mathrm{RT}=$ Reason of toxicity; $\chi^{2}=$ Chi-square; $P=$ Probability.

Although the Amazon region is one of the main centers of biodiversity, the reports of the plants with insecticidal properties are becoming more frequent from the 2000s (COITINHO et al, 2006; SILVA et al., 2007; SARRIA et al. 2011; ALVES et al., 2012; FAZOLIN et al., 2016; SANTOS et al., 2015, 2016). In general, botanical insecticides are less toxic than the synthetic ones and they degrade faster (ABBASSY; ABDELGALEIL; RABIE, 2009). Another advantage of botanical insecticides is the chemo-biodiversity of plants, which provides a variety of bioactive compounds against pests and significantly reduces the selection of resistant ones (PAVELA, 2009; PINO; SÁNCHEZ; ROJAS, 2013). The insecticidal activity of COR can be attributed to several identified chemical constituents, which belong to monoterpene, sesquiterpene, and diterpene classes (GERIS et al., 2008; LEANDRO et al., 2012).

Bioactivity studies of the chemical constituents found in COR and other botanical species revealed that they have different modes of action for insects (feeding inhibition and toxic activity repellency either by contact or by fumigation) (GERIS et al., 2008; ALVES et al., 2012; CHAUBEY, 2012; CÁRDENAS-ORTEGA et al., 2015; SANTOS et al., 2016). Recently, it was found that methanolic extracts of leaves and dried shells of Copaifera langsdorffi Desf. (Leguminosae-Caesalpinoideae) negatively affected the survival rate of caterpillars of $S$. frugiperda, increased protein excretion in caterpillars' feces, and inhibited the activity of trypsin in in vitro tests (ALVES et al., 2012).
The ratio of chemical components in these bioinsecticides as well as their synergism or antagonism effects primarily determine their effectiveness (HUMMELBRUNNER; ISMAN, 2001; MESBAH; MOURAD; ROKAIA, 2006; ABBASSY; ABDELGALEIL; RABIE, 2009; FAZOLIN et al., 2016). Increasing the efficacy of botanical insecticides by combining them with synthetic insecticides increases the chances of their use in the field. However, studies of mixtures of additive effects have been studied a little. In the present study, there was an additive effect, where COR mixtures + insecticide (triazophos, chlorpyrifos, methomyl and beta-cypermethrin) in ratios of $1: 1$ $\left(\mathrm{LC}_{25}+\mathrm{LC}_{25}\right)$ substantially increased the rate of mortality of larvae. According to Raffa and Priester (1985) the combined action of insecticides and oils may generate results as the sum of the effects of each compound or an overall effect higher than this sum, moreover, this mixture can minimize the environmental pollution by residues of insecticides persistent and preserve the beneficial insects.

In synergism tests, we found that the insecticidal activity of COR was enhanced when it was combined with triazophos, methomyl, or beta-cypermetrin because the toxicity of COR to caterpillars of $S$. frugiperda was substantially increased in these mixtures. According to Metcalf (1967), synergism is substantially more toxic or pharmacological action of two substances when used together. This combined action is the direct opposite of antagonism, in which the activity of the mixture is less than that of the more active constituent. 
Synergism is only considered when a constituent of a mixture (synergist), which is inactive in the dosage employed, is considerably more active than the other single component in the resulting mixture (MESBAH; MOURAD; ROKAIA, 2006; FAZOLIN et al., 2016).

Thus, the increased toxicity of COR in mixtures with inactive doses of the synthetic insecticides beta-cypermethrin, methomyl, and triazophos reduce the risks of selecting resistant populations of $S$. frugiperda. This is because the increased toxicity of mixtures containing insecticides is usually associated with the activity of biological compounds based on distinct mechanisms of action (CORBEL et al., 2006; AHMAD; SALEEM; SAYYED, 2009). Furthermore, the use of insecticide mixtures may help reduce the selection speed of resistant pest populations and may directly benefit insect resistance management programs (to insecticides) if there is no cross-resistance to the insecticides used in the mixture (MCKENZIE, 1996; SAYYED; AHMAD; SALEEM, 2008). The prospects for the successful use of the mixtures depend on the ability of each component to kill a very high percentage of the exposed insects, which are genetically susceptible to it (CURTIS; HILL; KASIM, 1993), and this is also expected considering the susceptibility patterns of $S$. frugiperda populations to COR. It is noteworthy, however, that the indiscriminate use of any botanical insecticide should be avoided because of possible harmful effects on non-target organisms, such as natural enemies (SUTHISUT; $\quad$ FIELDS; CHANDRAPATYA, 2011).

Overall, COR exhibited high toxicity to caterpillars when combined with nonharmful concentrations of insecticides. These results are very meaningful for integrated pest management programs, considering that deleterious effects in the early stages of $S$. frugiperda caterpillar development reduce crop losses (SALEEM et al., 2016; SANTOS et al., 2016). Therefore, our investigation about the potential of additive mixtures is essential for the management of $S$. frugiperda, which may have economic implications for maize producers as well as for producers who cultivate other crops susceptible to this pest. Therefore, the impact on the net income of producers is particularly important in developing regions, where phytosanitary techniques (plant protection) are often based on conventional methods. On the other hand, production has substantially increased in some developing regions such as the Brazilian Amazon region, even with a limited storage capacity. In general, the COR mixtures with synthetic insecticides (triazifós, methomyl and beta-cypermethrin) promoted the substantial increase in the toxicity of COR.

\section{CONCLUSIONS}

The copaiba oil mixtures with insecticides in the proportions of 1:1 $\left(\mathrm{LC}_{25}+\mathrm{LC}_{25}\right)$ displayed greater additive effect in COR mixtures with insecticides triazophos, chlorpyrifos, methomyl and beta-cypermethrin. Additionally, the toxicity of COR increased substantially in admixture with insecticides (1/8 of recommended rate of each pesticide), especially with lower mixtures with beta-cypermethrin, methomyl and triazophos. COR in mixtures highlights a potential alternative to be implemented in integrated-pest management programs of $S$. frugiperda.

\section{ACKNOWLEDGEMENTS}

Financial support provided by FUNTAC and CAPES were greatly appreciated, as was the technical assistance provided by Lucas Martins Lopes.

\section{REFERENCES}

ABBASSY, M. A.; ABDELGALEIL, S. A. M.; RABIE, R. Y. A. Insecticidal and synergistic effects of Majorana hortensis essential oil and some of its major constituents. Entomologia Experimentalis et Applicata, Hoboken , v. 131, n. 3, p. 225-232, 2009.

AHMAD, M.; SALEEM, M. A.; SAYYED, A. H. Efficacy of insecticide mixtures against pyrethroid- and organophosphate-resistant populations of Spodoptera litura (Lepidoptera: Noctuidae). Pest Management Science, Hoboken, v. 65, n. 3, p. 266-274, 2009.

ALVES, D. S. et al. Toxicity of copaiba extracts to armyworm (Spodoptera frugiperda). African Journal of Biotechnology, Ebène, v. 11, n. 24, p. 6578-6591, 2012.

AMBROZIN, A. R. P. et al. Limonoids from andiroba oil and Cedrela fissilis and their insecticidal activity. Journal of the Brazilian Chemical Society, Campinas, v. 17, n. 3, p. 542-547, 2006.

ARAÚJO JÚNIOR, F. A. et al. Efeito do óleo de copaíba nas aminotransferases de ratos submetidos à isquemia e reperfusão hepática com e sem pré-condicionamento isquêmico. Acta Cirúrgica Brasileira, São Paulo, v. 20, n. 1, p. 93-99, 2005.

BAVARESCO, A. et al. Biologia e exigências térmicas de Spodopteracosmioides (Walk.) (Lepidoptera: Noctuidae). Neotropical Entomology, 
Londrina, v. 31, n. 1, p. 49-54, 2002.

CÁRDENAS-ORTEGA, N. C. et al. Composition of the essential oil of Salvia ballotiflora (Lamiaceae) and its insecticidal activity. Molecules, Beijing, v. 20 , n. 5, p. 8048-8059, 2015.

CHAUBEY, M. K. Acute, Lethal and synergistic effects of some terpenes against Tribolium castaneum Herbst (Coleoptera: Tenebrionidae). Ecologia Balkanica, Plovdiv, v. 4, n. 1, p. 53-62, 2012.

COITINHO, R. L. B. C. et al. Atividade inseticida de óleos vegetais sobre SitophiluszeamaisMots. (Coleoptera: Curculionidae) em milho armazenado. Revista Caatinga, Mossoró, v. 19, n. 2, p. 176-182, 2006.

CORBEL, V. et al. Synergism between insecticides permethrin and propoxur occurs through activation of presynaptic muscarinic negative feedback of acetylcholine release in the insect central nervous system. Neurotoxicology, Amesterdã, v. 27, n. 4, p. 508-19, 2006.

CORRÊA, J. C. R.; SALGADO, H. R. N. Atividade inseticida das plantas e aplicações: revisão. Revista Brasileira de Plantas Medicinais, Botucatu, v. 13, n. 4 , p. 500-506, 2011.

CURTIS, C. F.; HILL, N.; KASIM, S. H. Are there effective resistance management strategies for vectors of human disease? Biological Journal of the Linnean Societ, Hoboken, v. 48, n. 1, p. 3-18, 1993.

FAZOLIN, M. et al. Synergistic potential of dillapiole-rich essential oil with synthetic pyrethroidç insecticides against fall armyworm. Ciencia Rural, Santa Maria, v. 46, n. 3, p. 382-388, 2016.

FRANCISCO, S. G. Uso do óleo de copaíba (Copaifera officinalis) em inflamação ginecológica. Femina, Rio de Janeiro, v. 33, n. 2, p. 89-93, 2005.

GERIS, R. et al. Diterpenoids from Copaifera reticulata Ducke with larvicidal activity agains tAedes aegypti (L.) (Diptera, Culicidae). Revista do Instituto de Medicina Tropical de São Paulo, São Paulo, v. 50, n. 1, p. 25-28, 2008.

GOUVÊA, S. M. et al. Lethal and behavioral effects of amazonian plant extracts on leaf-cutting ant (Hymenoptera: Formicidae) workers. Sociobiology, Feira de Santana, v. 56, n.3, p. 1-13, 2010.

HORIKOSHI, R. R. J. et al. Near-Isogenic Cry1F-resistant strain of Spodoptera frugiperda (Lepidoptera: Noctuidae) to investigate fitness cost associated with resistance in Brazil. Journal of
Economic Entomology, Oxford, v. 109, n. 2, p. 854-859, 2016

HUMMELBRUNNER, L. A.; ISMAN, M. B. Acute, sublethal, antifeedant, and synergistic effects of monoterpenoid essential oil compounds on the tobacco cutworm, Spodoptera litura (Lep., Noctuidae). Journal of Agricultural and Food Chemistry, Munich, v. 49, n. 2, p. 715-720, 2001.

ISMAN, M. B. Plant essential oils for pest and disease management. Crop Protection, Toowoomba, v. 19, n. 8-10, p. 603-608, 2000.

KASTEN JUNIOR, P.; PRECETTI, A. A. C. M.; PARRA, J. R. P. Dados biológicos comparativos de Spodoptera frugiperda (J.E. Smith, 1797) em duas dietas artificiais e substrato natural. Revista de Agricultura, Piracicaba, v. 53, n. 1-2, p. 68-78, 1978.

LEANDRO, L. M. et al. Chemistry and biological activities of terpenoids from copaiba (Copaifera spp.) oleoresins. Molecules, Beijing, v. 17, n. 4, p.3866-3889, 2012.

LIMA-MENDONÇA, A. et al. Efeito de pós vegetais sobre Sitophilus zeamais (Mots., 1855) (Coleoptera: Curculionidae). Arquivos do Instituto Biológico, São Paulo, v. 80, n. 1, p. 91-97, 2013.

MCKENZIE, J. A. Ecological and Evolutionary Aspects of Insecticide Resistance. Austin: Academic Press, 1996. 185 p

MESBAH, H. A.; MOURAD, A. K.; ROKAIA, A. $Z$. Efficacy of some plant oils alone and/or combined with different insecticides on the cotton leaf-worm Spodoptera littoralis (Boisd.) (Lepidoptera: Noctuidae) in Egypt. Communications in Agricultural and Applied Biological Sciences, Bethesda, v. 71, n. 2, p. 305-328, 2006.

METCALF, R. L. Mode of action of insecticide synergists. Annual Review of Entomology, Palo Alto, v. 12, n. 1, p. 229-256, 1967

OLIVEIRA, A. N.; AMARAL, I. L. Florística e fitossociologia de uma floresta de vertente na Amazônia Central, Amazonas, Brasil. Acta Amazonica, Manaus, v. 34, n. 1, p. 21-34, 2004.

OMOTO, C.; RODRIGUEZ, G. I. D.; Herança da resistência de Spodoptera frugiperda (J. E. Smith) (Lepidoptera: Noctuidae) a lambda-cialotrina. Neotropical Entomology, Londrina, v. 30, n. 2, p. 311-316, 2001

PAVELA, R. Effectiveness of some botanical insecticides against Spodoptera littoralis Boisduvala 
(Lepidoptera: Noctudiae), Myzus persicae Sulzer (Hemiptera: Aphididae) and Tetranychus urticae Koch (Acari: Tetranychidae). Plant Protection Science, Praha, v. 45, n. 9, p. 161-167, 2009.

PEREIRA, A. C. R. L. et al. Atividade inseticida de óleos essenciais e fixos sobre Callosobruchus maculatus (Fabr., 1775) (Coleoptera: Bruchidae) em grãos de caupi [Vignaunguiculata (L.) WALP.]. Ciência e Agrotecnologia, Lavras, v. 32, n. 3, p. 717 $-724,2008$.

PINO, O.; SÁNCHEZ, Y.; ROJAS, M. M. Plant secondary metabolites as analternative in pest management. I: Background, research approaches and trends. Revista de Protección Vegetal, La Habana, v. 28, n. 2, p. 81-94, 2013.

POTENZA, M. R. et al. Efeito de produtos naturais irradiados sobre Sitophilus zeamais Mots. (Coleoptera: Curculionidae). Arquivos do Instituto Biológico, São Paulo, v. 71, n. 4, p. 477-484, 2004.

RAFFA, K. F.; PRIESTER, T. M. Synergists as research tools and control agents in agriculture. Journal of Agricultural Entomology, Washington, v. 2, n. 1, p. 27-45, 1985.

RANI, P. U.; VENKATESHWARAMMA, T.; DEVANAND, P. Bioactivities of Cocosnucifera L. (Arecales: Arecaceae) and Terminalia catappa L. (Myrtales: Combretaceae) leaf extracts as post-harvest grain protectants against four major stored product pests. Journal of Pest Science, Ipswich, v. 84, n. 2, p. 235-247, 2011.

RÍOS-DÍEZ, J. D.; SALDAMANDO-BENJUMEA, C. I. Susceptibility of Spodoptera frugiperda (Lepidoptera: Noctuidae) strains from central Colombia to two insecticides, methomyl and lambda-cyhalothrin: a study of the genetic basis of resistance. Journal of Economic Entomology, Oxford, v. 104, n. 5, p. 1698-1705, 2011.

SALEEM, M. et al. Monitoring of insecticide resistance in Spodoptera litura(Lepidoptera: Noctuidae) from four districts of Punjab, Pakistan to conventional and new chemistry insecticides. Crop Protection, Toowoomba, v. 79, n. 1, p. 177-184, 2016.

SANTOS, A. C. V. et al. Use of plant oils from the southwestern Amazon for the control of maize weevil. Journal of Stored Products Research, Oxford, v. 63, n. 1, p. 67-70, 2015.

SANTOS, A. C. V. et al. Inseticidal oils from amazon plants in control of fall armyworm. Revista Caatinga, Mossoró, v. 29, n. 3, 2016.
SANTOS-AMAYA, O. F. et al. Resistance to dual-gene $\mathrm{Bt}$ maize in Spodoptera frugiperda: selection, inheritance, and cross-resistance to other transgenic events. Scientific Reports, London, v. 5, n. 1, p. 1-10, 2015.

SANTIAGO, G. M. P. et al. Avaliação da atividade larvicida de saponinas triterpênicas isoladas de Pentaclethra macroloba (Willd.) Kuntze (Fabaceae) e Cordia piauhiensis Fresen (Boraginaceae) sobre Aedes aegypti. Brazilian Journal of Pharmacognosy, Curitiba, v. 15, n. 3, p. 187-190, 2005

SARRIA, A. L. F. et al. Effect of triterpenoids and limonoids isolated from Cabralea canjerana and Carapa guianensis (Meliaceae) against Spodoptera frugiperda (J. E. Smith). Zeitschrift fur Naturforschung Section c - A Journal of Biosciences, Tubingen, v. 66, n. 5-6, p. 245-250, 2011 .

SAS INSTITUTE. SAS/STAT(R) 9.3 User's Guide. Disponível em: <http://support.sas.com/ documentation/cdl/en/statug/63962/HTML/default/ viewer.htm\#chap0_toc.htm>. Acesso em: 23 mar. 2011.

SAYYED, A. H.; AHMAD, M.; SALEEM, M. A. Cross-resistance and genetics of resistance to indoxacarb in Spodoptera litura (Lepidoptera: Noctuidae). Journal of Economic Entomology,Oxford, v. 102, n. 1, p. 472-479, 2008.

SILVA, H. H. G. et al. Larvicidal activity of oil-resin fractions from the Brazilian medicinal plant Copaifera reticulata Ducke (LeguminosaeCaesalpinoideae) against Aedesaegypti (Diptera, Culicidae). Revista da Sociedade Brasileira de Medicina Tropical, Uberaba, v. 40, n. 3, p. 264-267, 2007.

SUTHISUT, D.; $\quad$ FIELDS, $\quad$ P. $\quad$ G.; CHANDRAPATYA, A. Fumigant toxicity of essential oils from three Thai plants (Zingiberaceae) and their major compounds against Sitophilus zeamais, Tribolium castaneum and two parasitoids. Journal of Stored Products Research, Oxford, v. 47, n. 3, p. 222-230, 2011.

VEIGA JÚNIOR, V. F.; PINTO, A. C. O gênero Copaifera L. Química Nova, São Paulo, v. 25 n. 2, p. 273-286, 2002. 